\title{
DE ENRIQUE II A JUAN II: APROXIMACIONES DECIMONÓNICAS
}

\author{
Montserrat Ribao Pereira \\ Universidad de Vigo
}

La literatura española decimonónica, especialmente la romántica, vuelve sus ojos al medievo para reescribir la historia de sus grandes nombres desde una perspectiva contemporánea subsidiaria, en no pocas ocasiones, del contexto político o cultural en que se gestan los textos. Los Trastámara castellanos constituyen uno de los ejes argumentales de mayor productividad a lo largo de la centuria. La dinastía, nacida bajo el signo de la bastaría y el fratricidio, ofrece un amplio abanico de argumentos relacionados con las guerras civiles, las regencias, las aspiraciones más o menos legítimas al trono y la ambición política, que sirven a los escritores de pretexto idóneo para la reflexión sobre su propio tiempo. Reyes, nobles y cortesanos, en muchos casos poetas también, se convierten, de este modo, en protagonistas de novelas, dramas, romances y cuentos que colocan a los lectores ante sí mismos a lo largo del convulso y complejo siglo XIX.

En este monográfico reunimos diez trabajos que abordan, desde perspectivas estéticas y genéricas diferentes, la reescritura ochocentista de los primeros Trastámara de Castilla, desde Enrique II hasta Juan II, desde los hechos de Montiel (1369) hasta el ajusticiamiento de don Álvaro de Luna (1453), principio y fin de una época de contiendas bélicas y poéticas ante cuyos sugestivos argumentos sucumbieron los genios creadores más diversos.

Nuestro periplo se inicia con el estudio que Enrique Rubio Cremades lleva a cabo de El primogénito de Albuquerque, de R. López Soler, la primera novela histórica española -y acaso una de las más importantes de la narrativa histórica romántica- 
que se ocupa de la transición entre Pedro i y Enrique II, fundador de la dinastía. En él se ofrece un completo panorama de las fuentes de que parte el novelista, romances y crónicas, fundamentalmente, pero también de la historiografía literaria, que brinda cumplida noticia de la encrucijada histórica que vive Castilla en la segunda mitad del siglo XIV.

Noemí Catalán Romero repasa la pertinencia literaria de Enrique in en la novela y en el teatro románticos, así como su lectura, siempre a la sombra de Pedro I, vinculada a la búsqueda de una memoria histórica que refuerce la identidad nacional en la España isabelina.

Una nueva cala en la novela del XIX nos conduce a las décadas centrales del mismo, momento en que se desarrolla de forma notable la escritura histórica de autoría femenina. En este contexto, $\mathrm{M}^{\mathrm{a}}$ Ángeles Ayala se ocupa de La corona de perlas, que novela los ficticios y trágicos amores de tres de los hijos de Alfonso XI, Berenguela, Sancho y Enrique II, quienes ignoran el parentesco que les une. La autora de esta narración, Pilar Sinués, es, a juicio de Ayala, la escritora del canon isabelino que más contribuye al desarrollo de la ficción de carácter histórico.

Pero sin duda, uno de los personajes más relevantes en la reescritura que el XIX lleva a cabo en el ámbito que nos ocupa es don Álvaro de Luna, segundo condestable de Juan II de Castilla, y a él se dedican varios trabajos. Salvador García Castañeda explica el interés que el maestre suscita a lo largo del siglo, desde el relato en inglés de Trueba (The Fate of Luna) hasta un romance de ciego en los años 70, pasando por los romances del duque de Rivas y el drama que le dedica Gil y Zárate en 1840.

El teatro histórico es, precisamente, el género en que la lectura política de la corte del rey Juan resulta más evidente. Desde esta perspectiva aborda Leticia Placín Alonso su análisis del drama de Bonilla y María Ceide Rodríguez el de Morán. Poco conocida, la pieza de José María Bonilla Don Álvaro de Luna, condestable de Castilla (1838) lleva a escena la reivindicación liberal de su autor, comprometido con la causa antiabsolutista, inserta en una trama política y amorosa en la que Juan II castiga en su condestable la deslealtad que deriva de sus amores con la reina, Isabel de Portugal.

Casi simultáneamente estrena Jerónimo Morán Los cortesanos de don Juan II, que se publica a principios de 1839. El alegato liberal es muy claro en esta obra, que se representa como parte de una función en beneficio de los prisioneros cristinos en la acción de Maella. El trabajo de Ceide estudia la pertinencia de los personajes secundarios, cuyos enredos y confabulaciones reconstruyen, ante los espectadores románticos, el convulso tiempo de guerra civil que vive España en el momento de estos estrenos. 
La tercera pieza teatral sobre el condestable llega a las tablas en 1840 de la mano de Antonio Gil y Zárate. De su repercusión crítica coetánea se ocupa María del Carmen Rodríguez Lorenzo, que analiza las reseñas periodísticas aparecidas, tras el estreno, en las principales cabeceras de Madrid.

Además de las intrigas cortesanas, la presencia de poetas de Cancionero es una constante en los textos ambientados en la corte de Juan II de Castilla, sobre todo en el teatro y en la novela. En las dos de Manuel Fernández y González que estudia María Teresa del Préstamo Landín, Mena, Manrique, Santillán, Cota y el propio Juan Alfonso de Baena recitan sus versos en los certámenes poéticos que organiza el rey. Sus trovas, construidas por el novelista en un pretendido estilo y lengua del siglo xv, hilvanan las conjuras que cercan a las reinas (doña María primero, doña Isabel después), al condestable y al propio monarca, que se rodea de poetas y de poesía para sobrellevar las cargas del trono.

El acercamiento político a la figura de Álvaro de Luna se aborda también en el XIX desde la perspectiva carlista. Ceferino Suárez Bravo lleva a escena el drama Los dos compadres, verdugo y sepulturero en 1848, al abrigo del segundo levantamiento civil, y defiende los ideales del Antiguo Régimen. Años más tarde, en 1852, reelabora el mismo argumento de la pieza teatral en un poema narrativo donde confluyen la tradición fabulística y la romanceril, al tiempo que se atenúa significativamente el contenido político.

Para cerrar estas calas que la literatura del xIX realiza en los casi cien años que comprende el reinado de los primeros Trastámara de Castilla, Mónica Fuertes Arboix reflexiona sobre el papel de la Historia y de la literatura histórica en la conformación del espíritu nacional, tomando como punto de partida los postulados de Modesto Lafuente en su Historia General de España.

Este monográfico se inserta en el ámbito de trabajo del proyecto de investigación código FFI2015-64107-P (MINECO-FEDER, UE). Todos los trabajos que lo integran han sido evaluados por pares ciegos, de acuerdo con las normas de la revista Lectura y Signo, a la que agradecemos la acogida de esta sección entre sus páginas. 